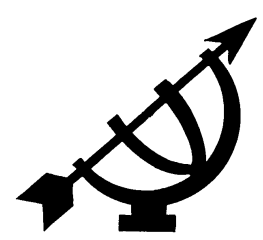

\title{
Integrity and consensus: A Christian perspective on ethical management and education in South Africa
}

\author{
Louise Kretzschmar
}

Dept. Systematic Theology \& Theological Ethics

University of South Africa

PRETORIA

E-mail: kretzl@unisa.ac.za

\section{Abstract}

Integrity and consensus: A Christian perspective on ethical management and education in South Africa.

In this article the compliance- and values-based approaches to ethical management are explained and the challenges of the contemporary business and societal contexts in South Africa noted. The need for both moral integrity and character (with respect to perception, intention and virtue) and ethical consensus is extensively discussed. The importance of ethical dialogue as a means of reaching moral consensus, and the contribution of public theology (particularly Christian theology) are assessed. Finally, vital issues relating to business ethics management and education are outlined and some practical possibilities suggested.

Opsomming

Integriteit en konsensus: 'n Christelike perspektief op etiese bestuur en opleiding in Suid-Afrika

In hierdie artikel word voldoening-en waardegebaseerde benaderings tot etiese bestuur verduidelik en die uitdagings van die huidige sake- en sosiale kontekste in Suid-Afrika uitgewys. Die noodsaaklikheid vir sowel morele integriteit as karakter (met verwysing na persepsie, intensie en eerbaarheid) en etiese konsensus word breedvoerig bespreek. Die belangrikheid van etiese dialoog as 'n metode om etiese konsensus te bereik, en die bydrae van openbare teologie (veral Christelike teologie) word bepaal. Ten slotte word kernkwessies met betrekking tot etiese sakebestuur en -opvoeding aangedui en verskeie praktiese moontlikhede uitgewys. 
It is a commonplace within business circles to stress issues of skill, competence and performance so as to achieve a required business result. What is less often stressed is ethical competence, by which is meant persons who have moral integrity, whose lives exhibit moral conduct and who can exercise ethical leadership. To stress technical competence in isolation from ethical competence is erroneous and shortsighted. The overemphasis on technical competence is erroneous because it wrongly conceives that ethical issues are unimportant when compared to factors such as profit, and it is shortsighted because it fails to note the devastation that can be caused to a business as the result of moral failure, especially by a senior manager (Elkington, 1999:234-286; Rossouw, 2001:135-144). Recent newspaper reports concerning the alleged mismanagement of Enron, the electricity company in the USA, exemplify the economic consequences of moral fallout. As reported in the Sunday Independent (2002:9) newspaper, Enron is:

... a Houston-based energy conglomerate. Last November it admitted overstating profits by almost $\$ 600$ million (about R6,84 billion) since 1997. Its share price collapsed from a high of more than $\$ 90$ in August 2002 to less than $\$ 1$. In December it became the largest American company ever to file for bankruptcy. What went wrong? Investigators believe senior executives used offshore partnerships to conceal huge debts. 1

A few weeks later, in the business report section of the Sunday Independent (2002:4), it was stated that the South African Institute of Chartered Accountants (SAICA) was addressed by the Minister of Finance, Mr. Trevor Manuel:

Manuel said that the Enron debacle had brought into sharp relief a number of key issues: Weak or non-existent governance structures; the fiduciary responsibility of directors; negligent and sometimes reckless management; ineffective auditing; and the independence of auditors and conflicts of interest arising from the inadequate separation between the provision of auditing and consultancy services. Closer to home, Manuel said, a number of corporate failures - Macmed, LeisureNet, Regal, UniFer - had raised similar issues, many of which had been highlighted in the Nel commission's report into the Masterbond affair.

Given the importance of ethics for business as illustrated by these examples, this article will first seek to clarify what ethical management is,

1 Between the time when this article was first written and when final changes were made prior to publication, a number of other corporate ethical scandals erupted. Additional companies, including WorldCom, were mentioned and investigations are still underway (Time, 2002:22-23). 
in terms of both compliance and values, and note some of the major challenges inherent in the business context in South Africa. Thereafter, the vital issue of ethical integrity is highlighted and the nature and means of moral formation discussed. The need to reach ethical consensus through dialogue, and the role of public theology are assessed. Finally, several issues vital to business ethics management and education are outlined and some practical possibilities suggested.

\section{Ethical management: compliance and values}

Although, in the field of moral philosophy, a distinction is sometimes made between ethics as intellectual reflection on conduct, and morality as actual conduct (eg. McDonald, 1995:xvi), this distinction will not be employed in this article. This is because the terms are often used interchangeably in Business Ethics texts (eg. Rossouw, 2002:3) and also because, in practice, it is not easy to distinguish between ethical reflection and moral conduct since they are often intertwined and impact upon each other. In this discussion, ethics/morality is seen as having to do with the promotion of what is good and right and the resistance of what is wrong and evil (sinful). The word "moral" is used here not simply in the limited sense of "not doing harm to others" (non-maleficence) but also in the positive sense of beneficence, that is, doing good and contributing to the welfare of one's neighbour and community. Ethics has to do with the attitudes, world views, character, and conduct of persons (together with their consequences) at both a personal and social level. It also deals with how persons can be motivated and empowered to live out meritorious values. In short, how can persons develop and display moral character and actions?

What, then, is ethical management? Ethical management in a business context can be defined as follows:

Business ethics management is largely about managing the risk to an organisation's reputation, and any risk management programme that does not include a strong emphasis on behaviour is fundamentally flawed. A programme component such as training, reporting systems and feedback-gathering mechanisms must be accompanied by the development of a broader values-based culture that employees see as consistent and believable (Moon \& Bonny, 2001:37).

Much has already been written in the field of ethical management in order to ascertain how best to effect ethical behaviour in a business environment. For example, in an article entitled "New Economy, New Ethics" written by Joel Hagan and Chris Moon (2001:26), the differences between compliance and value-based ethical programmes are outlined. Whereas compliance-based ethical programmes stress rules and 
regulations, value-led approaches seek to achieve "a match between the values of the company and those of the individual, so that the individual is intrinsically motivated to alter his/her behaviour" (Hagan \& Moon, 2001:26). In compliance-based ethical management programmes,

Employees are motivated to do the right thing through the fear of being caught rather than by a desire to be law abiding. Compliance is about obeying rules and authority. Programmes that concentrate only on compliance rarely help employees to resolve situations that are not covered by regulation. Such programmes do not attempt to develop employees' ethical autonomy and responsibility (Hoffman, Driscoll \& Painter-Morland, 2001:39).

Value-led approaches concentrate on the autonomy (the self-directed freedom and independence) of individuals:

Value-driven programmes focus on the company's values and principles and how they apply to situations where no particular rules apply. Employees are helped to become more aware of ethical dilemmas and to make ethically sound decisions. They are also encouraged to ask questions and raise any personal concerns (Hoffman et al., 2001:39).

In short, compliance programmes tend to stress institutional authority whereas value-led approaches tend to emphasise individual autonomy (Hoffman et al., 2001:38).

The newer emphasis on value-driven approaches has led to significant shifts of emphasis in certain companies. For example, Texas Instruments, the global semi-conductor company, has moved from a compliance-based ethical programme towards a greater emphasis on the company's core values. Rejecting the use of a cumbersome document, the company stressed three words: integrity, innovation and commitment (Hoffman et al., 2001:46). According to Robin Aram, Vice President of Shell:

We don't believe in requiring everyone to comply with detailed rule books. We believe in a value-based approach that basically says you are being paid in order to make the right decisions based on a certain set of values and principles. I think value-based approaches are going to be more sustainable in the long term (Moon \& Bonny, 2001:26).

These critiques of compliance-based ethics do not mean this approach has no merit. Despite its weaknesses, the ongoing worth of compliancebased ethical management is that it provides clarity concerning policies and procedures, and it creates a framework within which compliance can be regulated and enforced in a firm. The writing of a code of conduct is also often the first step towards taking ethics seriously in business circles. 
However, one of the biggest problems experienced by firms using codes of conduct are that some codes appear to have been enforced in a topdown manner, without full consultation and agreement by employees (Connock \& Johns,1995:66-87). This means that employees are unable to explain or implement such codes since they neither accept nor own them. This raises the issue of the importance of ethical awareness, ethical education and building moral consensus in order to achieve the successful use of compliance-based programmes. Even when valuebased programmes are used, the issue of the training of personnel (management and employees), and the ownership of the stated values by staff become central. Therefore, it is not helpful to draw too sharp a distinction between compliance and value-based ethical programmes, as both are important. Rather than being seen as competing, it would be better for rules and values to form an alliance in which they are "complementary components of an ethical programme" (Hoffman et al., 2001:42).

In a survey conducted in 1999 by researchers from Pennsylvania State University and the University of Delaware, it was found that the use of a code did not have such an effective influence on ethical behaviour. On the other hand, "consistency between policies and actions, the rewarding of ethical behaviour and executive leadership's attention to ethics has the greatest impact on controlling employee ethical conduct" (Moon \& Bonny, 2001:29). The real ingredients of success were found to be as follows: leadership; consistency between words and actions; fairness; openness; just rewards; and values-driven approaches (Moon \& Bonny, 2001:29). These findings highlight the importance of ethical management by example.

This stress on both compliance and value, on the one hand, and ethical leadership, on the other hand, indicates the vital need for greater ethical integrity. Arguably, what is needed to restore South African society is an understanding of ethical management which incorporates three elements: ethical enforcement (compliance), ethical direction and inspiration (values) and inner compulsion (integrity of character). These three elements can provide a means to further both the individual and common (social) good. But, before concentrating on this third aspect, that is, integrity, some comments regarding the context of business in South Africa are necessary.

\section{Business and society in South Africa today}

Only three matters will be touched upon here to provide a thumb-nail sketch of some of the challenges facing the South African nation. These include the need for both competence and integrity in personal and social 
life; the disparity, disunity and conflict in the nation; and the pluralistic nature of our ethical values and world views.

\subsection{The need for both competence and integrity}

At the outset of this article, the importance of both competence and integrity were stressed. But, are both consistently exhibited in South Africa?2 2 To begin with, there are those persons who are competent but lack integrity. People in this group almost inevitably abuse their positions of power in acts of self-aggrandizement and by exercising patronage to ill deserving supporters or extended family members. A second group consists of those have integrity, but lack competence. Whilst significantly less malign and evil-intentioned than the first group, such persons can wreck havoc within a company, organisation or government department by virtue of their inability to implement decisions or produce the required results. Worse still, there is a third group, those who lack both integrity and competence. Such persons exist in both corporate and governmental sectors. The capacity for graft, mayhem, manipulation and deceit among this category of people appears to be virtually limitless. They leave behind them a wreckage of lives and dysfunctional organisations, which mitigate against both institutional and public well-being. This leaves a fourth, sparsely populated category, that is, those who are both competent and have integrity. If South Africa is to have a prosperous future and take its place as a significant player on the African and world stage, the numbers of people that fall into this fourth, more desirable, category, need to be significantly increased.

\subsection{Dealing with the disparity, disunity and conflict in South Africa}

A second feature of the contemporary South African scene is that of disparity, disunity and conflict. At the macro level, a range of economic disparities and inequalities (eg. poverty, unemployment, land ownership, capital assets and skills) dominate the business scene in 21st-century South Africa. This is a complex society facing a hugely challenging future, whilst still encumbered by the millstone of an exploitative past. This has, understandably, an enormous impact on people's perceptions about economics and business.

2 Media reports regularly provide allegations (or evidence) of corruption and/or mismanagement. For example: "Old Mutual takes on the crooks" (Mail and Guardian, Sept. 27-Oct. 3, 2002:26) and "Taking corruption seriously" (Mail and Guardian, Sept. 20-26, 2002:9). See also Sangweni and Balia (1999a:27-86). 
South Africa is experiencing ongoing racial suspicion and conflict, albeit at different levels and in various ways. Race remains a central factor in the equation of South African society, exacerbated by the huge inequalities already mentioned, as well as power struggles and disputes concerning the interpretation and the implementation of the Employment and Equity Act. Moreover, terms such as transformation, reconstruction, transition and development are constantly used, but not necessarily understood in the same way. The relatively low value of the Rand (eg. compared to the Euro, British pound and US dollar) bears testimony to the lack of external confidence in our future. Whether the ongoing negotiations with respect to Nepad (New Economic Partnership for African Development) will have a positive impact on perceptions of and investment in Africa (on the part of both international players and Africans themselves), remains to be seen. Internal perceptions also vary, ranging from uncertainty and disillusionment to confidence and enthusiasm.

Within this broad context, many are concerned about the growth of the incidence of mismanagement, fraud, greed and corruption (Van der Walt, 2001:691-705). ${ }^{3}$ In a developing economy, where urgent attention needs to be given to economic growth, the country cannot afford the additional (and unnecessary) drain of fraud and the mismanagement of scarce resources (Rossouw, 2002:157-166). Nor, given the needs of the country in terms of the provision of extensive additional welfare services, education, skills training, housing, health and the like, should the existing infrastructure be permitted to fall into decay. But how, it must be asked, can South Africans from all sections of society be motivated to work towards a common and prosperous future if the economic and ethical perceptions, attitudes and agendas of the relevant participants are so disparate, even conflicting?

\subsection{The pluralistic nature of ethical values and world views}

A third important element of the South African context relates to the ethical pluralism of our society. Given the cross section of persons active in economic and business circles in South Africa today, for example, among labour, business and government leaders, several differing moral

3 Zulu speakers refer to the mabhense (those with big stomachs, who waste away the riches of other people, in other words, "fat cats"). Nor are such problems limited to South Africa. In the London Sunday Times of 4 June 1995 it was reported that twothirds of the leading companies in Britain have been victims of serious fraud by employees. The main motive was cited as being that of greed (Connock \& Johns, 1995:1). 
paradigms are to be found. These may be drawn, for example, from religious traditions (including mainly Christian, traditional African and Muslim groups) which stress transcendent values, that is, God is seen as the ultimate source of moral motivation and values. Religious injunctions include: "do not steal"; "be righteous and just"; "love your neighbour as yourself"; "a fully human person is one who is in relationship with and promotes the good of the community"; and "be compassionate and generous towards the poor".

In addition to, or instead of, a religious basis for morality, people may adopt one or more ideological approach or general world view. Some of the possibilities include economic functionalism (which concentrates on production and efficiency); humanism (which sees human beings and societies as the only source of moral values); communism (which stresses the materialist basis of life and seeks centralist control of the economy to effect a more equal society); and capitalism (which promotes the "free" market and deregulation of the economy as the best means of economic growth and distribution). Some approaches may be community and relationship-based (eg. the African emphasis on Ubuntu), whilst others, such as those based on individualist Western philosophical traditions, are centred in personal autonomy. 4

This raises the question of how the search for common values can best be conducted within a myriad of racial, cultural, gender and class interests. Using ethical dialogue, some degree of moral consensus regarding moral values, character and leadership will need to be found if ethical management in corporations using both compliance and valuesbased approaches is to be successful. But, more of moral consensus later.

In the context of these three broad challenges, it needs to be asked how the much talked about "moral regeneration" of the country can be effected. How can the "Ubuntu Pledge" agreed upon at the Moral Summit in October 1998, which begins with the commitment to "be good and do good" (Sangweni \& Balia, 1999b:51), or the National Integrity Strategy developed at the National Anti-Corruption Summit in April 1999 be implemented (Sangweni \& Balia, 1999b:46-51)? Furthermore, how can a sufficient degree of ethical consensus be reached, whereby individuals and groups in our divided society can agree to the joint implementation of certain virtues and values for the social good?

$4 \quad$ Painter-Morland (2001:16) provides a succinct summary of the contrasting views of Kohlberg (who sees individual principled reasoning as the highest moral stage), and Gilligan (1982) (who values an ethic of responsibility and care). 


\section{Moral integrity and character}

Moral integrity encompasses both honesty and wholeness (or integration). That is to say, a person of integrity is neither dishonest nor fragmented. According to Childs (1995:115):

To speak of integrity is to speak of being intact, whole, healthy, or integrated. When sin [moral evil] divides us within ourselves and from each other, our integrity as whole individuals and our integrity as persons created for community is destroyed. Similarly, reality of sin is experienced in the loss of integrity in our relationship with creation, a loss that threatens the integrity of nature itself.

Put differently, a person of integrity does not live a fragmented or dualistic life in which there is a separation between what they proclaim and how they act. Nor is a person of integrity "two-faced", behaving in one way when with one group and in an entirely different way with another group. A person of integrity is also not guilty of the compartmentalisation of life whereby there is a dissonance between what is regarded as acceptable behaviour at home and at work. For example, at home a person may practise the virtue of fairness, but at work be ruthless and unjust.

Whereas moral philosophers and teachers have for some time stressed principles of right and wrong, and this remains important,

... some are saying that our preoccupation with ethical problem solving has resulted in a neglect of concern for 'character', the sorts of people we are. These newer voices are suggesting that our moral development, our ethical formation and a shaping of our conscience are even more important than formulating the rules of right and wrong and applying them. Persons of integrity and communities with strong, clear ethical traditions possess the 'character' needed to do the right thing. An over-emphasis on decision-making puts the cart before the horse (Childs, 1995:72; Maclntyre, 1981:210-245).

As earlier scholars put it, actio sequitur esse (actions follow from who we are); good conduct is a consequence of good character (Foster, 1998:5796).

What, then, is moral character? According to William Brown, a person's character "is reflected in the tendency to act, feel, and think in certain definable ways" (Brown, 1996:6). A person of moral character is someone who displays qualities and actions that are worthy of emulation, someone who embodies values and virtues that can be regarded as normative. A moral character is someone "who is considered to possess sound judgement to know what is right and [has] the courage to act on it" 
(Brown,1996:7). Brown further identifies three elements of character, namely: perception, intention and virtue.

Perception goes beyond observation or description, it is the way in which persons selectively internalize and integrate events so as to create meaning for themselves. The way in which people perceive, select, interpret and assess events and actions is usually governed by their fundamental symbols, world views or paradigms. For Christians (and other religious believers) this fundamental paradigm is the will of God. For others it may be self-advantage, the will of the community, or something else. This paradigm is not fixed, it can be altered or even significantly changed, but it is the framework within which people's moral perceptions and imaginations operate. The possibilities of influencing or changing these perceptions through ethical dialogue and education are discussed in a later section of this article.

Intention refers to the will or volition. Intention is an expression of character and decision or purpose. Intention assumes free will (choice) and thus, accountability. Intentions are not simply isolated actions or decisions, they are coherent patterns of behaviour or conduct. In this sense, intention is a vital part of character. This means that persons in business will act ethically either because they are compelled to do so, or because they consciously decide and will to do so. Those who unwillingly comply will only act ethically if they are convinced that they will be caught and punished if they fail to comply. If given the opportunity to commit fraud without being detected, they are much more likely to succumb to the temptation than someone who is motivated by inner moral integrity. Hence, the success of a values-based ethical management approach, as discussed earlier, is linked to ethical integrity.

The third element of moral character, according to Brown, is virtue. Virtues, such as fairness, honesty and self-control, are dispositions or habits of behaviour that exhibit character. A virtue both reveals and expresses character; it reveals how persons are customarily disposed to act and it is an demonstration of who they are. Virtue can be a standard of character inasmuch as it is regarded as something which others are disposed to imitate and admire. Virtues are not static, but are made explicit through actions in life situations (Frankena, 1973:62-65). It is important to remember that virtues are not inborn: they are learnt or acquired through education and practice. This means that virtues need to be identified and nurtured. Unless moral formation is taking place in a society's schools, homes, communities, and places of work and also encouraged in the influential media, the chances of ethical conduct being widely manifested in the business world are slight. 
Particularly in a business environment, it is important to note that virtues are linked to moral habits and actions, they are not simply professional skills or abilities:

But, the appeal of recent popular literature is in large measure due to a blurring of the boundaries between moral virtues and skills of success. According to the classical ethicists, however, moral virtue is no guarantee of success, and success is not necessarily a sign of moral integrity. The appeal of the virtuous life is intrinsic. Distinct from professional skills, moral virtue is characteristic of a 'unitary life'. In other words, moral virtues tend to cut across all situations of conduct, from professional to personal. To compartmentalize the virtue of honesty by relegating it to, for example, one's personal life but excluding it from one's professional conduct, is no virtue. Virtues are by nature all encompassing (Brown, 1996:10-11, my emphasis - LK).

Along with perception and intention, then, virtues are part and parcel of character. When these three act in unison, it is possible to speak of someone as having moral integrity and character. How, then, can moral integrity be nurtured or formed?

\section{Moral formation}

\subsection{What is ethical formation?}

Moral formation can be defined as the development of a person's moral character which results in moral conduct. It is a process which leads to a person's character and conduct reflecting stated moral values. Moral formation is a broad term that incorporates moral socialisation and education (Van der Ven, 1998:81-124). (If socialization is the way in which individuals learn to function within a social context, moral socialisation is the means by which a society passes on the values which it expects members to develop and exercise.) Moral formation includes both informal (often unconscious) means of formation (such as observing and imitating behaviour) and formal and deliberate means of formation (such as cognitive discussion of moral values and virtues). Parents, teachers, peers, and other influential persons are all agents of moral socialization. Moral teaching provides persons with standards, principles, rules, and values by which to live and these form part of the moral framework of society. Also very important are the perceptions and moral habits people form, or the moral choices they make, in response to their life experiences.

Moral formation involves the development and expression of virtues and values. As argued earlier, virtues are much more than traits of personality, they are morally excellent qualities of character and conduct such 
as courage, fairness, kindness, honesty, accountability and self-control (Frankena, 1973:63). Values are principles that people admire and seek to emulate and, hence, they govern our perceptions (or attitudes) and behaviour (McDonald, 1995). Thus, someone who values justice will seek to act in a consistently just manner, even at some cost to their selfinterest. Conversely, someone who places primary value on his/her own wealth or status, will act mainly in self-interest. Even apparent acts of generosity or fairness towards others will often mask the real motive of self-advancement.

Also important is the development of moral conscience. Conscience may be defined as "an inner voice" or internal sense of compulsion which either encourages or discourages certain behaviour. A person's moral conscience is developed by the influence of their parents or family, by imbibing the values of a particular group, in obedience to the will of God, on the basis of personal moral conviction, or a combination of all of these. 5

But how is this to be achieved? Much of the current literature on Business Ethics somewhat neglects the issue of what makes us moral, focusing rather on the importance and lack of ethics, ethical rules and codes (to ensure compliance), discussion of ethical values, an analysis of ethical theory (to assist in ethical decision-making), or specific aspects of Business Ethics (eg. marketing or accounting) (Chrysiddes \& Kaler, 1993; Bradman, 2001). But what does one do, for example, with a manager who does not espouse ethical values or exhibit moral character? How can such a person suddenly be educated into becoming ethical competent, let alone able to exercise ethical leadership? Even though some texts on business ethics, as cited earlier in this article, increasingly emphasize values-based ethical competence over ethical compliance, insufficient attention is given to the moral development of the individual person both prior and subsequent to their appointment to a particular position within a company.

\subsection{How does moral formation occur?}

Moral formation takes place in a number of different ways including through the agency of one's family, school, peers and the impact of one's social experience. Personal effort, formal or informal mentoring, values

5 See the input of David Wells regarding the modern "loss of the self" which prevents moral formation (Wells, 1998:99 ff.) and Covey's discussion of "primary greatness" or self-mastery (Covey, 1991:57-66); public victories will only be possible if preceded by private victories - victories over self (Covey, 1992:40 ff.). 
and punishment also have an impact on moral formation. People are influenced by both their conscious thoughts and their unconscious fears, needs and ambitions. 6 Human beings are complex and their moral values and perceptions cannot be reduced to a few simple formulas. In order to effect behaviour, improve human relations, and encourage values such as innovation, commitment, integrity and productivity at work, it is necessary to come to understand the roots of our own moral values and judgments as well as those of others.

A person's childhood and family context both play a very significant role in moral formation (Van der Ven, 1998:81-89). The moral perception of adults can often be traced back to childhood or teenage experiences. People are further morally formed by their religious context or overarching moral framework, as noted earlier in this article. This framework enables people to make judgments about right and wrong, even if they fail to consistently live according to these stated principles or values (see Kretzschmar, 1997 \& 2002).

Moral formation does not occur by accident. Virtues are formed by being exercised or practised. As Aristotle said many centuries ago: "... we become just by the practice of just actions, self-controlled by exercising self-control, and courageous by performing acts of courage" (Nicomachean Ethics, 1103b:30-37). Just as physical fitness requires training and exercise so, too, does moral fitness. Thus, the development of virtue takes places only as a result of a determined effort and the application of personal choice. According to Kotva (1996:6):

... we learn virtues through practice and in the company of others. We learn virtues by imitating worthy role models, listening to the advice of virtuous friends and teachers, hearing the stories of virtuous people, and following rules of virtuous behaviour.

Individual moral competence is thus shaped in the context of a social community. This social environment includes the political, economic, cultural, and gender contexts that influence what people believe and how they act. According to the ethicists, Bruce Birch and Larry Rasmussen, character is the "chief architect of our decisions and actions" and the community is the "chief architect of character" (Birch \& Rasmussen, 1989:81). For most people, the local community in which they are nurtured consists of the close and extended family, as well as friends, neighbours and the people with whom they associate on a regular basis. conversion, obedience to God, the enabling of the Holy Spirit and the nurture and discipline of the Christian community playing an additional, transformative role. 
Religious believers are further located within a particular faith community which provides additional, often contrasting, moral socialization:

Moral rules, consequently, cannot operate independently of the formation of character in traditions transmitted and shaped by the community. Rather, principles and rules are part and parcel of the dynamics of character formation in that they contribute to the community's task of providing particular conceptions of good through which character is formed (Brown, 1996:14).

This means that personal moral integrity and behaviour cannot be separated from the formation and preservation of appropriate communal life.

It is at this point that the importance of narrative is revealed. Stanley Hauerwas has stressed the link between character formation, on the one hand, and community life and narrative, on the other hand (Hauerwas, 1981; Richardson, 1994). According to Hauerwas, people are formed by stories and metaphors more than by rules. 7 Therefore, the importance of emulation (and imagination) in the formation of character must not be overlooked. In narrative, characters come alive and hearers are encouraged to imitate certain characters and avoid the conduct of others. Stories "acquaint us with lives of virtue" (Brown, 1996:18). In a business context, using stories of company heroes, virtues such as self-control, fairness, honesty, openness, and courage can be illustrated and emulated. Such virtues are particularly impressive when contrasted to stories about the personal and institutional destructiveness of vices such as the lack of self-control, unjust actions, lies, dishonesty, manipulation and intimidation.

It is significant that inasmuch as communal life deteriorates, such as is the case in both Africa and the West, moral consensus and discipline must of necessity also diminish. Furthermore, in South Africa, where no single "community" exists and intense suspicion reigns, moral consensus for our society needs to be negotiated before it can be implemented.

\section{Reaching consensus through dialogue}

Moral formation in a pluralistic context, in order to be successful, needs to seek moral consensus through dialogue. This is a process of identifying which values and virtues members of a business community agree company compared to the often diminished moral effectiveness of managers of large conglomerates (Childs, 1995:71). 
and ought to be implemented. Some work has already been done in this regard. For example, religious and political leaders jointly agreed at the Moral Summit of 1998 to endorse a Code of Conduct which embraced these values: integrity, incorruptibility, good faith, impartiality, openness, accountability, justice, respect, generosity and moral leadership (Sangweni \& Balia, 1999b:48-49). Judge Mervyn King stresses the four pillars of fairness, accountability, responsibility and transparency which need to rest on the foundation of intellectual honesty (King, 2001:25). However, intellectual acceptance of these is not enough. A thorough analysis of what they mean in practice, a public ritual of commitment to these values, and the utilisation of processes that test and enforce compliance to these stated commitments are essential next steps.

Why does acceptance of such values require ongoing negotiation and consensus? In an unequal, divided, suspicious and pluralistic context, such as is exemplified by the moral crisis facing South Africa, no one group can impose its moral perceptions or expectations upon another. This does not mean that individuals need to sink to the level of the lowest common denominator, still less that they need to subsume their moral values and convictions to an ethos that is in conflict with their convictions. Rigorous ethical dialogue is a much better alternative.

Writing within a North American context, Childs (1995:6-13) stresses the importance of dialogue between religion and business. In particular, he stresses the need for both Christian groups and business leaders to address the "rising tide of ethical concern". This concern is prompted by the low standards of ethical conduct at both a senior and junior level in corporations. Childs has identified a number of factors that cause what he calls a "shareability gap" between business, on the one hand, and Christianity, on the other hand:

1. In our secular world the conviction lingers that objective reason can lead us to moral truth along a path of neutrality.

2. A tendency to equate Christian ideals with a few commonly held principles short-circuits more probing moral reflection.

3. Among many Christians there remains a long-standing dualist assumption that spiritual life and business life belong to separate worlds.

4. The church has often been hostile in its attitude toward business and has tended to neglect addressing the specific daily needs of those in business.

5. Businesspeople often operate with a stereotype of the church as out of touch with the 'real world' and incapable of understanding that world (Childs, 1995:6-10). 
Childs points out that the philosophical legacy of the Enlightenment has given to many modern business leaders a trust in reason and empirical research. Many seek to take a detached rational or objective view of the corporation (Childs, 1995:3-4). As a result of postmodernism, however, many people are becoming more sceptical concerning the possibility of "sound reason" supplying a sufficient answer, particularly given the pluralistic context in which business, particularly international business, operates. 8

With reference to the book After Virtue, by Alasdair Maclntyre, Childs notes the fact that carefully reasoned arguments do not bring decisive resolution to ethical problems. This failure of reason has left the door open to emotivism, which simply makes personal subjective judgments about what is right or wrong. It is summed up in the phrase, "if it feels good, do it" (Childs, 1995:31). This leads to systemic moral cynicism in society, and also in business:

Systemic moral cynicism is a hostile environment for the nurture and growth of individual ethical integrity, not only by providing little incentive for integrity but also by punishing its expression through direct or indirect means (Childs, 1995:32)

For example, whistle-blowers are seldom rewarded and are often punished for bringing to the public's attention the unethical behaviour of a manager or corporation. In these instances, "individual integrity is frustrated, the organisation is weakened and, in fact, may lose more than just the loyalty and contribution of the individual; talented people of high principle often simply leave" (Childs, 1995:33). In terms of Child's analysis:

For MacIntyre the failure of Enlightenment rationalism to establish a moral consensus is rooted in its secularist rejection of any ideal of human fulfilment. Catholic and Protestant theology, as well as Greek humanism, have provided Western culture with an understanding of humanity's true end, a vision of what authentic human life is all about. However, secularism rejected all of these visions ... Because there is no longer an authoritative vision of such an end, the ethical precepts it [secularism] spawned are empty of meaning and authority, even though we continue to evoke them (Childs, 1995:34).

8 Modernists, dating from 17th century Europe, stress science, reason, individual equality and material reality and they tend to be religious sceptics. Postmodernists seek to recover previously discarded spiritual experience, symbols and cultural values, they are sceptical of reason and truth claims and tend to be moral relativists. 
This means that in seeking to promote the development and impact of personal moral integrity on social and business life, a new vision of human fulfilment and meaning needs to be identified. What contribution can religion and, in this instance, the Christian faith, make to this discussion?

The theologian Hans Küng, argues that only religious traditions have the transcendent character that can elevate ethical commitments above the self-interest of individuals and groups (Childs, 1995:36; Küng, 1991). This means that the public role of religions, such as the Christian and other faiths, is essential in the formation of a negotiated and consensual public moral paradigm to which all can be held accountable. This is a point also made by Ronald Thiemann, Dean of Harvard Divinity School, who speaks of pluralism as giving us all "ethical vertigo". In response, he says:

Public theology is faith seeking to understand the relation between Christian convictions and the broader social and cultural context within which the Christian community lives ... to identify the particular places where Christian convictions intersect with the practices of contemporary political life (quoted in Childs,1995:38). (For further information also see Thiemann, 1991:19-20 - LK.)

This stress on the contribution of religious traditions to the development of moral insights, character and moral consensus, does not imply sectarian dominance, that is, the domination of one religion or a subgroup within a religion. In other words, both the pole of pluralism and its opposite, sectarian religion, need to be rejected in favour of a more central, pivotal position, mainly, public theology. Public theology, then, is the contribution made by a religious tradition to the public or common good.

If what Maclntyre and Childs say about secularism is true, that is, that it provides neither transcendent values nor a common vision of a personal or social good, how can ethics be taught at a tertiary level to business (or public sector) managers so as to result in an improved focus on ethical competence?

\section{Teaching ethics - Business Ethics programmes in tertiary education}

Can one teach business ethics in a university, college or business context in such a way that the completion of one or several courses can have a positive impact on both moral character and conduct? In other words, education that goes beyond the transferal and regurgitation of knowledge? This all depends on what one understands the purpose of 
ethical education to be. Should moral education be a deliberate programme which seeks to identify agreed upon ethical goals and establish a means of encouraging (or enforcing) ethical conduct in the business environment?

In an article dealing with tertiary education and business ethics in South Africa, Deon Rossouw outlines three approaches to the purpose of teaching business ethics (Rossouw, 2001). These he defines as leading to cognitive competence, behavioural competence, and managerial competence. According to Rossouw, cognitive competence concentrates on acquiring intellectual knowledge and skills and managerial competence seeks to enable managers to be ethically competent (Rossouw, 2001:43-44). Behavioural competence, however, stresses the importance of developing "the capacity of students to behave morally in a business setting" (Rossouw, 2001:43). What is needed to build behavioural competence, says Rossouw, "is attention to the affective [emotional], volitional and imaginative dimensions of ethics" (Rossouw, 2001:43). (See also Whetstone, 1998:177-206.)

Anthony (1987:69) has spoken of "education for justice", that is, the type of education that goes beyond the exchange of information to personal and social conversion and renewal. Education for justice means that individuals need to be exposed to the lives and world views of those in their society (or business environment) with which they would not normally mix or interact. As both Brown and Rossouw have said, this includes a renewal of perception and a revised imagination or vision concerning the nature of persons and society. ${ }^{9}$

To be even more specific, in terms of the education and training of employees, the following factors are regarded as important in terms of the best practice framework. All employees must be morally educated, the way wrongdoing occurs must be identified, realistic examples need to be provided, and there must be sensitivity to diverse employee groups (Moon \& Bonny, 2001:35). All too often,

Business ethics education is rather hit-and-miss. Some companies do invest in ongoing education and training, with simulations and scenarios to keep participants interested. For many companies, though, such education does not make use of real issues that employees encounter. Best practice indicates that realistic examples with sensitivity to the

9 This renewal of perception could include the incorporation into business paradigms, of the triple bottom line (economic prosperity, social justice and environmental sustainability) (Elkington, 1999; see also Klein, 2001). 
diversity of employee groups can provide more awareness of ethical issues (Moon \& Bonny, 2001:36).

In ethical training, a number of issues are important: employees need to be empowered to think through ethical issues and consequences, their diverse backgrounds need to be taken into account, and sufficient opportunities to exchange views provided. Ethical programmes which are too brief, have insufficiently prepared participants, or fail to consider the larger context of a company, are doomed to failure (Mavuso \& Balia, 1999). Good ethics training sessions should take the following actions:

- clarify the ethical values and enhance the ethical awareness of employees;

- uncover and investigate ethical issues and concerns that directly relate to the organisation;

- discuss criteria for ethical decision-making within the organisation;

- examine and enrich the structures, strategies, resources, policies and goals that shape the ethical environment and guide the ethical activities of the organisation (Hoffman et al., 2001:46).

A number of practical guidelines emerge from what has been said thus far:

1. Awareness. Assess the moral needs and conduct of employees and companies and identify the (competing) moral voices. In this regard, a variety of sources including relevant case studies and stories, television or video programmes, and widespread discussion can be utilised to lead to the cognitive moral competence spoken of by Rossouw.

2. Dialogue. Engage the group in dialogue as to which are central values, virtues and visions and how they are to be interpreted and implemented within a company context. The goal here is to establish moral consensus as to what is agreed upon so that all can be held accountable.

3. Opportunity to express intention. Provide the opportunity for individuals to make specific commitments in a public way so as to integrate personal conviction and communal accountability.

4. Develop integrity and build character to foster behavioural competence. Engage in a variety of processes and programmes in which persons can be morally conscientised, educated, encouraged, mentored and formed in terms of agreed-upon values and virtues.

5. Assure implementation. Unless the moral consensus reached is seen to be implemented, via both compliance and values-based ethical management (including the imposition of appropriate penalties), any 
programme of moral management will fall apart. If managers lead by moral example, managerial competence will also be exhibited.

\section{Conclusion}

This article has stressed the importance of the development of ethical competence. In this regard, both values and compliance-based ethical management programmes are important. In particular, the vital role of the development of ethical integrity and character, which includes a specific focus on moral perceptions, intentions and virtues, has been stressed.

In a divided society, moral management and education in a business context require ethical dialogue, to both attain consensus and make implementation possible. Cognitive, behavioural and managerial moral competence can be significantly advanced using specific educational programmes which use a combination of codes of conduct, discussion regarding virtues, values, visions and the use of appropriate stories. But, in order to be effective, these need to be combined with visible accountability and ethical leadership by managers. In all of these ways, I suggest, moral integrity, conduct and leadership can be advanced in the South African business environment.

\section{Bibliography}

ANTHONY, Susan B. 1987. Sidewalk Contemplatives: A Spirituality for Socially concerned Christians. New York : Crossroads.

ARISTOTLE. C 335-323BC. Nicomachean Ethics. (Translated by M. Ostwald.) Englewood Cliffs : Prentice Hall. 1962.

BIRCH, B \& RASMUSSEN, L. 1989. Bible and ethics in the Christian life. Minneapolis : Augsburg.

BRADMAN, R. 2001. Understanding Business Ethics. London : Continuum.

BROWN, William P. 1996. Character in Crisis: A Fresh Approach to the Wisdom Literature of the Old Testament. Grand Rapids : Eerdmans.

CHILDS Jr., JAMES, M. 1995. Ethics in Business: Faith at Work. Minneapolis : Fortress.

CHRYSSIDES, George D. \& KALER, John H. 1993. An Introduction to Business Ethics. London : International Thomson Business Press.

CONNOCK, Stephen \& JOHNS, Ted. 1995. Ethical Leadership. London : Institute of Personnel and Development.

COVEY, Stephen R. 1992. Principle-Centred Leadership. London : Simon \& Schuster.

ELKINGTON, John. 1999. Cannibals with Forks: The Triple Bottom Line of 21st Century Business. Oxford : Capstone.

FOSTER, Richard J. 1998. Streams of Living Water: Celebrating the Great Traditions of the Christian Faith. New York : HarperCollins.

FRANKENA, W. 1973. Ethics. Englewood Cliffs : Prentice Hall.

GILLIGAN, Carol. 1982. In a Difference Voice: Psychological Theory and Women's Development. Cambridge, Massachusetts : Harvard University Press. 
HAGAN, Joel \& MOON, Chris. 2001. New Economy, New Ethics. (In Moon, C. \& Bonny, C., eds. Business Ethics: Facing up to the Issues. London : Profile Books, p. 7-21.)

HAUERWAS, S. 1981. A Community of Character: Towards a Constructive Christian Social Ethic. Notre Dame : University Press.

HOOFMAN, W. Michael, DRISCOLL, Dawn-Marie, \& PAINTER-MORLAND, Mollie. 2001. Integrating Ethics into Organisational Cultures. (In Moon, C. \& Bonny, C., eds. Business Ethics: Facing up to the Issues. London : Profile Books, p. 38-54.)

KING, Mervyn. 2001. Good Corporate Governance: A Fundamental Value for New Citizenship in South Africa. (In Defining a New Citizenship for South Africa and the Fundamental Values that will Shape It. Johannesburg : Konrad Adenauer Stiftung, Seminar Report No. 10. p. 21-27.)

KLEIN, Naomi. 2001. No Logo. London : Flamingo/HarperCollins.

KOTVA, J.J. 1996. The Christian Case for Virtue Ethics. Washington, DC : Georgetown University Press.

KRETZSCHMAR, L, 1997. The gap between belief and action: Why is it that Christians do not practise what they preach? Scriptura, 62:311-321.

KRETZSCHMAR, L. 2002. Authentic Christian Leadership and Theological Education in Africa. Journal of Theology for Southern Africa, 113:41-60.

KÜNG, H. 1991. Global responsibility. New York : Crossroad.

MACINTYRE, Alasdair. 1981. After Virtue, Notre Dame, Indiana : University of Notre Dame Press.

Mail and Guardian, September 20-26, 2002:9.

Mail and Guardian, Sept 27-October 3, 2002:26

MAVUSO, Vusi \& BALIA, Darryl. 1999. Fighting Corruption: Invitation to Ethics Management. Pretoria : University of South Africa Press.

McDONALD, J. Ian H. 1995. Christian Values: Theory and Practice in Christian Ethics Today. Edinburgh : Clark.

MOON, C. \& BONNY, C. 2001. Attitudes and Approaches. (In Moon, C. \& Bonny, C., eds. Business Ethics: Facing up to the Issues. London : Profile Books. p. 22-37.)

PAINTER-MORLAND, Mollie. 2001. Weaving the Moral Fabric of the South African Workplace: Personal and Institutional Factors. (In Strengthening the Moral Fabric of the South African Workplace: Strategies, Resources and Research. Johannesburg : Konrad Adenauer Stiftung. Seminar Report No. 9. p. 15-25.)

RICHARDSON, Neville. 1994. Ethics of Character and Community. (In Villa-Vicencio, C. \& De Gruchy, J.W., eds. Doing Ethics in Context. Cape Town : David Philip. p. 89-101.)

ROSSOUW, Gedeon J. 2001. The Role of Tertiary Education in Teaching and Research in Business Ethics in South Africa: Problems, Initiatives and Challenges. (In Strengthening the Moral Fabric of the South African Workplace: Strategies, Resources and Research. Johannesburg : Konrad Adenauer Stiftung. Seminar Report No. 9. p. 41-47.)

ROSSOUW, Gedeon J. 2002. Business Ethics in Africa. Oxford : University Press.

SANGWENI, Stan \& BALIA, Darryl. 1999a. Fighting Corruption: Strategies for Prevention. Pretoria : University of South Africa Press.

SANGWENI, Stan \& BALIA, Darryl. 1999b. Fighting Corruption: Towards a National Integrity Strategy. Pretoria : University of South Africa Press.

Sunday Independent, February 3, 2002:9

Sunday Independent, February 24, 2002:3.

THIEMANN, Ronald F. 1991. Constructing a Public Theology. Louisville, KY : Westminster/John Knox Press. 
Time, August 12, 2002:22-23.

VAN DER VEN, Johannes A. 1998. Formation of the Moral Self. Grand Rapids : Eerdmans

VAN DER WALT, B.J. 2001. Corruption: A Many-Headed Monster. Koers, 66(4):691705.

WELLS, David F. 1998. Losing our Virtue: Why the Church must Recover its Moral Vision. Leicester : Intervarsity Press.

WHETSTONE, J.T. 1998. Teaching Ethics to Managers: Contemporary Problems and a Traditional Solution. (In Cowton, C. \& Crisp, R. Business Ethics: Perspectives on the Practice of Theory. Oxford : OUP. p. 177-206.)

\section{Key concepts:}

moral dialogue, consensus and formation

ethical management and education

moral integrity

\section{Kernbegrippe:}

morele dialoog, konsensus en vorming

etiese bestuur en onderrig

morele integriteit 